\title{
Transparency Policy Implementation Process Manado City Government
}

\author{
Arie Supriati, Theodorus Pangalila
}

\begin{abstract}
The Implementation of the Transparency Policy as a technique used to adequately carry out local government civic duties, by the Manado City Government, is aimed at organizing transparent and accountable local governance in accordance to Law No 14 of the Year 2014 on public information disclosure. This study aims at determining and implementing a transparency policy of the administration. Data was collected using the descriptive qualitative technique, and the result found that the current implementation process passes through various stages as viewed from policy substance, thereby making the process less effective with numerous obstacles. The purpose of this study is to create a transparency policy which is easy to access information by the community. The following were suggested in the research. The need to develop a legal umbrella for local regulation, to gain access to all elements of the policy such as actors, implementers as well and the policy objectives Secondly, it is accountable to public information disclosure.
\end{abstract}

Index Terms: policy implementation, transparency, government.

\section{INTRODUCTION}

The philosophy of pleasant governance illustrates the principle of clarity, which is justifiable. The principle does not only refer to the formulation mechanisms, its implementation, policy evaluation, activities, or programs, instead it also creates opportunities for people to suggest, counter, and reprimand government strategies.

In line with the actualization of the transparency or openness principle, the government enacted and implemented Number Law 14 of 2008 on Public Information Disclosure. This created an avenue for the public to gain access to information on various public strategies and assessment. Furthermore, the government needs to be committed to the right of its citizens, to ensure proper implementation of transparent and democratic governance that is free, and truthful, with nondiscriminatory information on its procedures and programs.

As anticipated by the local government in line with the 2004 Law Number 32 regarding regional government, community participation in development is seen by the extent to which the community accesses and exercises various forms of social control over local government policies. Therefore, the local government, along with the City Council of Manado, is aimed at organizing a responsible and transparent system.

Irrespective of the fact that Law 14 of the 2008 Public Information Transparency policy has been executed and enforced in Manado city, however, the fact remains that the

Revised Manuscript Received on April 19, 2019.

Arie Supriati, Lecturer, Department of Pancasila and Civic Education, Faculty of Social Sciences, Manado, Indonesia.

Theodorus Pangalila, Lecturer, Department of Pancasila and Civic Education, Faculty of Social Sciences, Manado, Indonesia. transparency policy is expected to assist the public in accessing information from the government without restrictions. In accordance with the description described, an in-depth study on the phenomenon was conducted on this research.

\section{LITERATURE REVIEW}

\section{A. Implementation of Public Policy}

The implementation of public policy which is one of the activities in the public policy process is often contradictory notwithstanding the fact that the policy product is capable of restricting the policymaker itself. Therefore, its implementation requires a genuinely profound understanding of public policy studies. In order words, the context associated with the implementation, comprises of several categories. The first drafts the program with a comprehensive explanation of tasks, formulation of unclouded objectives, as well as the determination of clear achievement concerning cost and time. Secondly, it implements programs by utilizing structures, personnel, funds as well as other resources, and their right procedures and techniques. Thirdly, Set up a suitable program, endeavor to supervise it regularly and in addition to assessing the policy implementation (1). Additionally, public policy deals with processes, techniques, operations, and the proficiency of authorized executives to interpret and employ public policy to accomplish and understand the desired vision and expectations. This view will help researchers better understand public policy, even though it has been formulated correctly in its implementation, its realization is challenging.

\section{B. Policy Implementation Model}

The policy leads to the implementation and actualization of models. Many factors determine the success of policy implementation, and each is interconnected. To deepen the understanding of several factors involved, the Merilee S. Grindle Model defined the implementation theory as a political and administrative process which is driven by the policy's content and its background. It also claimed that the process of policy implementation starts once the aims and goals have been developed, the action programs outlined, and some cash reserve assigned to accomplish these aims and targets. According to Charles O. Jones, implementation of policies is an exercise proposed to perform a program while concentrating on three principal actions; 1) Arrangement, creation or transferring of resources, units and 
procedures to aid in the proper functioning of the program, 2) Interpretation and understanding of the program, 3) Function, which deals with the operation of conventional activities involving the prearrangement of goods and services. This also confirmed the viewpoints that alters, restricts, and accedes are important approaches in implementation techniques.

Transparency in the execution of Good Governance can be described as reliable and effective development management by democracy, prevention of misallocation of insufficient investment revenues and the avoidance of crime both politically and administratively, executing financial discipline, developing legal certainty and political environment for the progress of entrepreneurial exercises. The phrase good governance means upright, democratic and impressive governance of government. The execution of suitable governance management within the government cannot be divided from the execution of a governance management system that constitutes several results of the execution of management services (preparation, formulating, actuating and controlling) conducted expertly and regularly. Execution of the management system can lead to a beneficial alliance among the government, private firm sector, and the society. Hence, it is anticipated of the government agency environment to offer exceptional service to society.

Although, Sedarmayanti, discloses that good governance is the practice of establishing state power in executing the provision of public goods and services known as governance. Hence, transparency in the management of local government can be observed in the following; 1) one form of government responsibility to the masses and 2) resolution to enhance the management of effective governance and administration. This decreases favorable circumstances for collusion, corruption, and nepotism $(\mathrm{CCN})$ practices. Transparency is one of the important necessities for developing good governance. Once there is transparency in every policy and resolution in the organization and government, decorum can be developed. Therefore, transparency is the government's impartiality in postulating information linked to the publics' resource management systems and also ensuring that this information gets to individuals need it.

\section{Transparency in Local Government Implementation}

The most important ethics of transparency in the management of provincial government is the principal that reveals the privilege of the public to get appropriate, truthful and fair information concerning the management of the local government while preserving the security of the personal, state and secret rights of the state. Execution of the transparency principle in the local government management permits the society to understand different information concerning the effective and fair management of society. Transparency of local governance creates an opportunity for the public to become aware of "make decisions and the reasons behind such decisions." Utomo stated that the conception and execution of regional autonomy don't vary from the definition and the utmost aim would add illuminate the good governance for a government that comprises of elements, receptive, effective, culpable, challenges, and requests of the region. Hence, the local government can guarantee that the autonomy of the region and society would soon be accomplished (5). According to the aforementioned illustration of transparency, this offers the theory that transparency problems are things that need to be accomplished with the scheme of achieving an effective governance. Transparency or clarity in Manado City governance is a combined obligation between the parliament and the city government. Hence, the notion of transparency of government administration in Manado City can be checked out on www.manadokota.co. All necessary information is clearly stated there. Interested individuals can learn the procedure of creating, planning, utilization, and determination of government programs via the website above.

\section{METHODOLOGY/MATERIALS}

This study would illustrate and examine the execution technique of the transparency procedure of Manado City administration utilizing qualitative methods with a case study. Manado City Government implemented the $14^{\text {th }}$ law on public information revelation in 2008. Data was obtained from policymakers (Chairman and members of Manado City Council, Head of Communication Information Section of Manado City, Head of Statistic of Manado City, Head of Manado Regional Supervisory Board, Deputy Head of Bappeda and Community Leader). The data selection procedures were dialogues, reviews, documentation, and FGD. Data examination was conducted during and after data collection. Additional data were collected, presented, and concluded in the end

\section{RESULTS AND FINDINGS}

\section{A. Profile of Manado City as City of Transparency Policy}

Manado is the largest city in the entire Northern region of Indonesia and the metropolis of North Sulawesi province which is topographically suited between $1025^{\prime} 88$ "- 10 39'50" LU and 124047 '00 "-1240 56'00 "BT and it's outer limits are surrounded by the following:

a. North side: North Minahasa region

b.Eastside: North Minahasa Region

c.Southside: Minahasa region

d.Westside: Sea of Sulawesi

Manado City has an area of 15,726 hectares. The coastal bay reclamation scheme began in 1995, and since then the entire area of Manado metropolitan has increased by approximately 67 hectares with 452,213 resident in 2015. It organizational Structure is based on government regulations number 41 of 2007 on Regional Device Organizations comprising of Regional Secretariat (3 Assistants, 13 Sections); Secretariat of the Council (4 Sections); 18 Officials, 14 Regional Technical Institutions (10 Agency, Regional Archive Office, Inspectorate, Unit civil service police and Corps employee republic Indonesia), 9 Subdistricts, 87 Urban Village, 504 Environments, and 2 Regional Companies. It had a total of 8.544 employers. The 
employee status according to rank is illustrated as follows:

$\begin{array}{ll}\text { GroupIV } & : 2.526 \text { people }(29.57 \%) \\ \text { GroupIII } & : 4.458 \text { people }(52.18 \%) \\ \text { GroupII } & : 1.492 \text { people }(17.47 \%) \\ \text { GroupI } & : 67 \text { people }(0.78 \%)\end{array}$

(Data source: BKD Manado City, 2014)

The concept of Mid-Term Development of Manado City Ecotourism simply means an attempt to increase and at the same time, maintain the probable natural resources and culture to act as tenable source revenue. The study area is the National Park area, the Bunaken National Park. The responsibility of Manado City 2010-2015 is to ensure is a friendly municipal to ascertain a metropolitan of comfort where people achieve their potentials and visions.

The grand strategy of its development is as follows: and Peace

2. Creating a Comfortable Urban Environment.

3. Building Identity and City Image as a Model of World Ecotourism

4. Increasing Manado's Role in Regional Economic Development

5. Implementing Good and Clean Governance.

\section{B. Manado City Government Implementation}

In the execution of transparency policy implementation of the government in conducting administrative jobs, the local government exhibits its obligation in conducting understandable and obligated local governance as stated in law number 14 of the 2008 public information disclosure. The transparency scheme, as illustrated above, has been through orderly and determinable phases that are dependent on the decrees suitable and acknowledged

by the local government and the city's legislature.

To examine the execution procedure of the scheme, it isimportant to examine the following; 1) entity of the policy. 2) Strategies adopted in its execution . 3) Target Group

According to law 14 of 2008 on public information disclosure, it was stated that the execution of a transparent metropolitan had been deliberated upon by the head of the district, mayor and deputy mayor to reach a compromise.

To analyze Law Number 14 of 2008 on public information disclosure in accordance to the implementation, the researchers conducted the following strategies: 1) Objectives 2) Scope 3) Benefits.

These are described as follows:

The purpose of its implementation as a form of responsibility in carrying out the systemic tasks of regional governments as previously stated, the council reveals its obligation in conducting clear and trustworthy local governance. A notable change is required for honesty in all spheres of governance, particularly in the issues of public services like;

Information that has to do with the whole growth preparation procedure either vision/mission urban development program, yearly organization beginning from the metropolitan village, sub-district, and municipal level.

State budget revenues information from the results of the discussion at the city level, and the budgeting process in determining State budget revenues. 2011-2015 is; "Manado Model City for Ecotourism."

1. Realizing the life of a Qualified Society, Pillars,

Spatial planning information at the inception of the implementation result.

Implementation of a physical and non-physical development project from the result of activity allocation, the appointment of a tender committee to winner submitted to the community.

Observations procedure begins from the evaluation of supervised objectives, management of people, and audit result.

- Hence, it is deduced that the extent of information revelation concerning the transparency of Manado metropolitan administration is to create information that must be acknowledged by the government, in addition to authorization and retributions for local government work entities or public organizations that do not produce information.

- Merits of transparency policy for Manado City Governance; natives or individuals expect the government to provide excellent services. Every society in the region needs the services of the government, however, in the course of these tasks, a lot of people think that public services in the area are still exposed to exploitation and are likely to be out of service. Out of service simply means the service is usually hidden or purposely hidden, handled via an inaccessible, questionable, and unaccountable behavior.

Besides the dialogues carried out by analysts in engaging and increasing the merits of transparency policy, analysts have conducted Forum Group Discussion (FGD) on the results obtained on Thursday, April 02, 2015.

The essence of this review is to get a more detailed interpretation of the execution procedure of the transparency policy of governance in Manado City. It was concluded in this review that transparency of the Manado City administration offered a lot of benefits to the inhabitants of Manado metropolitan.

One of the merits associated with this type of governance is that the public is obligated to provide adequate support to the government in decreasing collusion, corruption, and nepotism $(\mathrm{CCN})$.

Secondly, inhabitants openly engage in policy schemes initiated by the government. They also have the right to acquire information on the policies initiated which also has a notable effect on democratization and attempts to develop good governance (Source FGD, April 2, 2015).

According to some respondents who attended the Forum Group Discussion held on April 2, 2015, the zeal of the Manado city government in implementing the principle of good governance is seen in online media with it transparent administration.

In the Group Discussion Forum, the following conclusions were obtained:

The transparency policy is useful, and the public is allowed to gain access to information directly through www.manado.kota.co.id or other media outlets.

The mayor is aimed at ensuring a transparent government administration, where the public is able to ascertain the development of regional financial balance daily 
through its Post balance media.

Its implementation in all Local government units of the administrative section.

Therefore, it is concluded that transparency not only provides benefits in creating good governance while preventing the practice of corruption but also improves quality public participation and supervision.

As previously described, community involvement is required and the society plays an essential role. Good governance exist if its citizens are mutually supportive, responsible, active, and conscious, in collaboration with a responsive, transparent, and listening government.

Therefore, it is important for the government to involve the community before making any decision. This is carried out to minimize the emergence of conflicted society, and the application of transparency principles, which requires honesty, in its implementation.

\section{CONCLUSION}

Based on the previous description of the results of the implementation process in Manado city governance, it is concluded that the process has passed through variety of stages . Its implementation and policy targets run effectively to create accessible information.

From the results of the above conclusions, the researchers suggested the following: (1). Commitment to the various elements of the policy for its actors, implementers, and objectives to be jointly responsible for its implementation. (2). It needs to be strengthened in the law as a legal umbrella.

\section{REFERENCES}

1. Tachjan. Implementasi Kebijakan Publik. Bandung: Puslit KP2W Lemlit UNPAD; 2006.

2. Wibawa S, Prabuningrat Y, Pramusinto A. Evaluas Kebijakan Publik. Jakarta: Raja Grafindo Persada; 1994.

3. Jones, Charles O. Pengantar Kebijakan Publik (public Policy). Ismanto R, editor. Jakarta: Raja Grafindo Persada; 1996.

4. Sedarmayanti. Good Governance (Kepemerintahan yang baik) dalam Rangka Otonomi Daerah. Bandung: Mandar Maju; 2010.

5. Utomo W. Admnistrasi Publik Baru Indonesia, perubahan Pradigmac dari Adninistrasi Negara ke Administrasi Publik. Yogyakarta: Pustaka Pelajar; 2006.

\section{AUTHORS PROFILE}

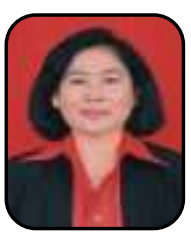

First Author Arie Supriati is a lecturer in the Department of Pancasila and Civic Education, Faculty of Social Sciences, Manado State University. She obtained her Bachelor of Pancasila dan Civic Education from Malang State University, Masters in Human Resources from Sam Ratulangi University Manado and Doctor of Human Resouce Program of Jakarta State University. The author actively examines the learning of citizenship education, especially concerning the topic of public policy and education.

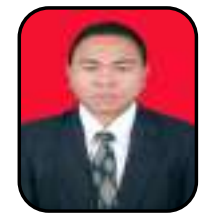

Second Author Theodorus Pangalila is a lecturer in the Department of Pancasila and Civic Education, Faculty of Social Sciences, Manado State University. He bagged a Bachelor of Philosophy Education from the Philosophy College of Pineleng Seminar, Masters in Citizenship Education from the Indonesian University of
Education Bandung and Doctor of Social Sciences from Merdeka University Malang. The author actively examines the learning of citizenship education, especially concerning the topic of sociology of citizenship 